\title{
PERILAKU MANUSIA DALAM PERSPEKTIF PSIKOLOGI ISLAM
}

\author{
Yuriadi \\ Universitas Trunojoyo Madura (UTM) \\ Email: adiettugmail.com

\section{Abstrak} \\ Perilaku merupakan hasil dari proses akumulasi psikologis individu \\ yang ditampilakan dalam ruang sosial. Landasan yang dijadikan \\ prinsip utama dalam menuangkan perilaku itu bermacam-macam, \\ salah-satunya berasal dari basis agama, yang dalam psikologi itu \\ dikenal dengan spikologi Islam. Islam adalah sumber dari segala \\ sumber dalam pendidikan akhlak termasuk di dalamnya adalah \\ perilaku dalam hal ini adalah perilaku Islam. Seorang yang \\ memahami Islam dengan benar serta menjalankan segala aturan \\ agama tersebut, akan tercermin melalui kemuliaan perilaku yang \\ ditunjukkan dalam bentuk akhlak sehari-hari. Kehidupan sehari-hari, \\ kita masih sering melihat seseorang yang melakukan tindakan \\ akhlak yang buruk meskipun kita lihat sehari-harinya ia adalah \\ sosok yang tekun menjalankan ibadah. Menjalankan ibadah tanpa \\ dibarengi dengan pemahaman dan upaya yang keras bisa merubah \\ diri ke arah yang lebih baik akan menyebabkan seseorang hanya \\ menjalankan ibadah secara fisik, namun hati dan pikirannya jauh \\ meninggalkan rutinitas ibadah tersebut. Sehingga akhirnya, ibadah \\ hanya tinggal ibadah secara fisik. Ruh dan pikiran tidak merasakan \\ efek dari ibadah tersebut. Seseorang yang rutin menjalankan ibadah \\ secara fisik tetap akan bisa menjalankan dosa, karena ia tidak pernah \\ menghadirkan ibadah tersebut dalam hati dan pikirannya.
}

Kata kunci: Perilaku Manusia dan Psikologi Islam

\section{Absract}

Behavior is the result of the accumulation of individual psychological processes shown in the social space. The cornerstone of which is used as the main principle in the pouring behavior is diverse, one only comes from the basis of religion, which in psychology is known Islamc Psychology. Islam is the source of all sources in moral education including the behavior in this case is unIslame behavior. A person who understands Islam properly and perform all the religious rules, will be reflected through the glory of the behavior shown in the form of everyday morality. Everyday, we 
still often see someone who acts bad character even though we see every day he was someone who diligently to worship. To worship without coupled with understanding and efforts to transform itself into a better direction will cause a person to worship only physically, but his mind and heart away to leave the routine of worship. So finally, worship is only pray physically. Spirit and mind are not feeling the effects of such worship. Someone who routinely run physically pray will still be able to run a sin, because he never brings such worship in his heart and mind.

Key Words: Human Behavior and Islamc Psychology

\section{Prolog}

Gerakan besar-besaran Islamisasi ilmu pengetahun telah merebak kemana-mana termasuk di Indonesia yang mendorong ilmuwan muslim melaksanakan Islamisasi sains. Terkotaknya antara sains dan agama yang mengakibatkan segala bentuk perilaku manusia dapat dikaji secara ilmiah. Ini terlihat dari semakin majunya peradaban suatu negara karena kemajuan sains, membawa dampak keberbagai keilmuan sosial dan termasuk psikologi di dalamnya. Kalangan ilmuwan Barat sendiri mulai melirik kembali untuk memperhatikan agama dalam sains, meskipun masih ada paradigma dalam keilmuan mengganggap agama sebagai bagian masa lalu sains yang saat ini harus ditinggalkan. Keinginan ilmuwan muslim untuk melihat kembali kejayaan muslim seperti pada abad pertengahan dapat mentransfer berbagai bentuk pengetahun dari budaya Yunani dan Romawi. Ilmuwaan di dunia muslim saat ini tampaknya mirip dengan situasi umat Islam di abad pertengahan itu, ini bukanlah sekedar utopia ilmuwan muslim yang sedang dalam posisi underdog, tetapi secara obyektif hal ini juga diakui oleh ilmuwan Barat sendiri. Bahkan beberapa ilmuwan memprediksikan akan adanya perseteruan dan pertempuran kebudayaan (setelah perseteruan antara dua super-power dunia), yaitu pertentangan antara budaya Barat dan budaya Islam, yang salah satu di antaranya adalah di bidang ilmu pengetahun sosial yang mempengaruhi perilaku individu.

Kejumudan dalam memberi batasan yang jelas dan tegas terhadap istilah Psikologi agama. Kesulitan ini terjadi karena terdapat dua aspek substansial ilmu yang terkandung dalam ilmu ini, yakni ilmu jiwa dan agama. Keduanya memiliki karakteristik berbeda dan sulit dipertemukan. Psikologi atau ilmu jiwa memiliki sifat "teoritik empirik dan sistematik", sementara agama bukan merupakan "ilmu pengetahuan atau saintifik". Agama merupakan suatu aturan yang menyangkut cara-cara bertingkahlaku, berperasaan, berkeyakinan, dan beribadah secara khusus. Agama 
menyangkut segala sesuatu yang semua ajaran dan cara melakukannya berasal dari Tuhan, bukan hasil karya dan hasil pikir manusia. Sebaliknya, psikologi merupakan hasil karya dan hasil pemikiran manusia. Psikologi menyangkut manusia dan lingkungannya.

Psikologi Islam terlihat sebagai reaksi atas psikologi modern. Ia tidak benar-benar memisahkan dirinya dari psikologi modern, bahkan mengakui psikologi modern dengan cara membuang aspek-aspek yang kontra-Islam. Selanjutnya, ia memformulasikan diri sebagai psikologi modern yang mengalami proses filterisasi dan di dalamnya mendapatkan wawasan keislaman. Bentuk formulasi seperti ini menjadi tujuan sementara dari psikologi Islam, dan akan disepadankan dengan menggali konsep-konsep Islam mengenai manusia dan kepribadiannya yang dirasa memerlukan waktu yang panjang. Kalangan menyebut model psikologi Islam merupakan bentuk reaktif umat Islam atas keilmuwan Barat. ${ }^{1}$

Madzhab psikologi modern yang positivistik diintegrasikan dengan pendekatan al-Qur'an yang hanya digunakan secara esoteric dan memiliki fungsi justifikatif, justru menimbulkan anomali baru. Karena, psikologi Islam yang didekati dengan sistem metodologi yang masih positivistik (adanya problem demarkasi sain-nonsain, verifikasi fakta, memberi tekanan pada kerja induktif, yang sangat kentara adalah kebutuhan untuk mendapatkan objektifitas sebuah keilmuwan di dalam Psikologi Islam). Penggalian keilmuwan Islam sebagai sebuah entitas normatif-dogmatik yang tidak tersentuh oleh kritik, refleksi, dan persesuaiannya dengan konteks historis. Psikologi Islam fase pertama ini mengasumsikan proses pengetahuan yang dapat dilakukan dengan cara mengetahui langsung dari alQur'an, dengan cara meletakkan tafsir sebagai aktifitas sekunder. Djamaluddin menyebutkan kita harus mampu membedakan kebenaran alQur'an dan kebenaran penafsiran al-Qur'an. Secara mutlak al-Qur'an adalah benar, tetapi penafsiran atasnya mungkin saja bias. Oleh karena itu rumusan tentang apa dan siapa manusia yang didasarkan pada al-Qur'an juga mungkin mengandung bias, karena bias dalam penafsirannya. Kalau perbedaan penafsiran terjadi, maka tugas kita adalah mengembalikannya kepada al-Qur'an. Al-Qur'an tidak pernah salah dalam memandang siapa manusia, yang salah adalah penafsiran atasnya. ${ }^{2}$

\footnotetext{
${ }^{1}$ Sumintarja, Elmira N. 2000. Konsep Manusia Menurut Psikoanalisa: Eksplanasi, Kritik, dan Titik Temu dengan Psikologi Islam. Yogyakarta; Pustaka Pelajar: hal. 24

2 Djamaluddin Ancok, Fuad Nashori. 1995. Psikologi Islam: Solusi Islam atas Problem-problem Psikologi. Yogyakarta; Pustaka Pelajar: hal.57
} 
Olson dan Hergenhahn berpendapat penyebab utama perilaku tidak pernah bisa disadari betul, dan biasanya berakar di masa kanak-kanak, pencarian atasnya sangat rumit. Peralatan yang cukup kompleks dibutuhkan bagi pencarian ini, seperti analisis mimpi dan simbol, asosiasi bebas, hypnosis, dan analisis tumpang-tindihnya kenangan. Pikiran bawah-sadar dapat memanifestasikan diri dalam kesadaran lewat beberapa cara, manusia tidak bisa sungguh memahami banyak hal dari seseorang dengan hanya mempelajari pengalaman sadarnya. Teorisi kepribadian yang memegang pandangan ini tidak bertanya kenapa seseorang melakukan sesuatu dengan cara tertentu karena penyebab sesungguhnya perilaku biasanya tidak diketahui olehnya. Untuk memahami kepribadian, siapa pun harus menyelami manifestasi pikiran bawah sadar yang berubah-ubah agar bisa diangkat ke pikiran sadar. Manusia sebagai diri yang memiliki kemampuan multidemensi harus menyelami di balik topeng manusia yang sudah dibekali akal. $^{3}$

Orang-orang yang beragama (Islam) yang kreatif mempergunakan akal dan qalbu-nya lebih optimal. Individu itu memiliki wadah kognitifspiritual yang lebih luas, dan individu itu dapat belajar bermacam-macam ilmu, apat menyerap lmu secara cepat dan luar biasa banyaknya. Akibatnya, kemampuan untuk menerima pengetahuan begitu luar biasa. Genius dalam berbagai bidang dapat ditemukan dalam diri ilmuan Islam, dan sangat sedikit ditemukan dalam diri ilmuan non-muslim. Ilmuan Islam seperti Ibnu Sinā, al-Ghazāii, Ibnu Haitham, dan yang lain adalah orang-orang yang menjadi ahli dalam bermacam-macam bidang atau disiplin ilmu. Ilmuan barat hanya mencatat nama Leonardo da Vinci sebagai orang yang sukses di beragam lini. Orang-orang yang beragama (Islam) juga lebih optimal dalam kreatifitas, karena kreatifitas yang dihasilkan dibuat dalam kerangka $\mathrm{ibadah}^{4}$. Orang yang terbaik adalah orang yang bermanfaat bagi orang lain, demikian ungkap Nabi dalam sebuah hadits. Orang yang terbaik adalah yang dapat melakukan peran sebagai khalifah (pemimpin) di bumi. Orang yang terbaik adalah yang mengaktualisasikan konsep rahmatan li al-'ālamīn.

\section{Pembahasan}

Islamisasi ilmu pengetahuan mendorong kejian Psikologi Islam melihat manusia yang memiliki perilaku didorong oleh multiple keinginan

\footnotetext{
${ }^{3}$ Matthew H. Olson\&B.R. Hergenhahn. 2011. Pengantar Teori-Teori Kepribadian. Yogyakarta: Pustaka Pelajar.hal: 104

${ }^{4}$ Sayyid Quthb, 2002. Tafsìr fỉ Zilāl al-Qur'an. Jakarta; Gema Insani Press. Hal; 207
} 
yang berasal dari pengetahuan dan pengalaman dalam kehidupan keseharian mereka.

\section{Akal sebagai Sumber Kemajuan}

Penggunaan akal secara optimal juga banyak memberikan sumbangan untuk tercapainya kejayaan umat Islam. Kemajuan yang diperoleh masyarakat Barat disadari oleh keyakinan bahwa akal adalah hal yang menjadi kelebihan manusia atas makhluk yang lain. Orang Barat melakukan upaya agar akal manusia dapat secara optimal digunakan dalam kehidupan individu keseharian. Orang Barat mendorong penduduknya untuk menjadi kreatif. Berbagai penghargan telah diberikan orang barat kepada insan-insan kreatif. Sejak lama orang Inggris memiliki Guinnes Book of the World Records. Orang Amerika menghargai para kreator. Umat Islam pun semestinya mempergunakan akalnya secara optimal agar kreatifitas itu dapat diraih. Proses pendidikan di Indonesia perlu didorong untuk mengoptimalkan penggunaan akal, namun tidak hanya dalam pengertian menghafal (atau istilah Benjamin Bloom sebatas knowledge). Harus dilakukan upaya agar orang memiliki kemampuan menghafal yang baik.

Cara untuk menjadi penghafal adalah dengan melatih menghafal alQur'an. Hafalan memang penting, tapi harus dilengkapi kemampuan berfikir yang lebih tinggi, yaitu kemampuan menggunakan pengetahuan untuk memahami realitas. Kebiasaan berfikir analisis-sintesis akan memungkinkan seseorang mengaktifkan akalnya. Tidak kurang dari itu, akal pun perlu dilatih untuk menemukan jalan baru atas berbagai masalah kehidupan. Pengaktifan hati sudah semestinya dilakukan untuk meraih keunggulan. Sebuah hadits Nabi mengisyaratkan bahwa mufarridun (orang-orang yang unggul) adalah orang-orang yang banyak melakukan dzikir. Keimanan juga mengaktifkan qalbu. Begitu pula dengan ibadah. Demikian juga amal sosial yang berbasis rasa keagaman dan juga penalaman keagamaan. ${ }^{5}$ Mengapa dzikir membuat orang menjadi unggul, tidak lain adalah dzikir memungkinkan hati berperan lebih aktif. Salah satu fungsi hati nurani adalah menerima pengetahuan atau ilham dari Allah. Kalau seseorang kreator muslim menghadapi masalah maka akan memperoleh jalan keluar, suatu ide yang berasal dari Allah. barang siapa yang bertaqwa kepada Allah niscaya dia akan menggandakan baginya jalan keluar (QS. al-Ṭalaq [65]:2).

Olson dan Hergenhahn proses kognitif di bidang teori kepribadian. Proses-proses yang seperti ini menentukan bagaimana informasi dari

\footnotetext{
${ }^{5}$ Nahori, H.F. dan Mucharam, R.D. 2002. Mengembangkan Kreatifitas: Perspektif Psikologi Islam. Yogyakarta; Menara Kudu: hal.209
} 
lingkungan diserap, diingat, ditransformasikan dan ditindaklanjuti oleh manusia. Teori-teori yang menekankan proses-proses kognitif biasanya tertarik kepada perilaku yang dengan sadar diatur diri sendiri, dan berfokus kepada pentingnya penghargaan-diri atau penghukuman-diri, yang berasal dari tercapai-tidaknya tujuan, lebih daripada penghargaan atau hukuman yang datang dari sumber di luar diri. Teori-teori yang berorientasi kognitif juga cenderung menitikberatkan perilaku dan tidak begitu mengindahkan pentingnya masa lalu. ${ }^{6}$

Prinsip keterpaduan akal dan wahyu, ilmu dan agama merupakan genuine pendidikan Islam yang memberikan ruang dan penghargaan tinggi terhadap pendidikan rasional dan spiritual. Keterpaduan akal dan wahyu merupakan keterpaduan sumber ilmu dalam pandangan Islam. Akal dapat menjadi sumber ilmu yang sah untuk hal-hal yang bersifat non fisik yang indera-indera lahiriah manusia tidak bisa berfungsi maksimal untuk menangkap hal-hal dengan sifat abstrak yang disebut ma'qulät (the intelligibles), sebagaimana indera-indera dapat menangkap hal-hal yang bersifat mahsüsät (benda- benda inderawi/fisik). Karena keterbatasan akal, maka perlu alat pencapaian ilmu lain yang lebih langsung menyentuh jantung objeknya, yaitu intuisi dan hati, yang perolehan tertingginya adalah hati. Wahyu harus dijadikan sebagai sumber yang kaya otoritatif bagi ilmu, khususnya bagi hal-hal yang ghaib, karena ia berasal dari Tuhan yang menciptakan alam-alam ghaib tersebut, dan karena itu punya otoritas yang luas untuk memberitakan mereka melalui firman-firman-Nya. Dengan demikian, epistemologi Islam telah mengintegrasikan seluruh sumber ilmu yang bisa dimiliki manusia dalam suatu kesatuan yang utuh dan holistik. ${ }^{7}$ Ilmu akan mengajarkan manusia memiliki moral untuk dapat bersanding baik dengan sesama, tanpa ada bentuk agresifitas.

Kekuatan moral dibutuhkan untuk mengendalikan akal dan nafsu sehingga kehidupan manusia menjadi lebih bermakna. Mengapa manusia harus bermoral/beretika? Jawabannya adalah karena manusia makhluk yang berakal, segala perbuatan, tindakan, dan perkataan manusia harus dipertanggungjawabkan. Perbuatan makhluk berakal senantiasa dinilai. Perbuatan yang bernilai itulah yang menjadikan kehidupan manusia menjadi bermakna. Hidup manusia tidak hanya sekedar melangsungkan spesies, tetapi bagaimana ia dapat bertanggung jawab terhadap diri sendiri, keluarga,

\footnotetext{
${ }^{6}$ Matthew H. Olson\&B.R. Hergenhahn. 2011. Pengantar Teori-Teori Kepribadian. Yogyakarta: Pustaka Pelajar: hal.254

${ }^{7}$ Mulyadi Kartanegara. 2005. Integrasi Ilmu: Sebuah Rekonstruksi Holistik. Bandung: Mizan Pustaka: hal. 38- 39
} 
masyarakat bangsa/Negara dan kemanusiaan secara umum. Tuntuntan tanggung jawab ini meyangkut kegiatan manusia dalam segala bidang. Fenomena ini akan mengantarkan manusia akan lebih baik dari sebelumnya. Moralitas memberikan kesempatan kepada individu untuk dapat menjadi ilmuwan yang bisa menggunakan pengetahuannya.

Sikap ilmiah yang harus dimiliki oleh setiap ilmuwan adalah kejujuran dan kebenaran. Nilai kejujuran dan kebenaran ini merupakan nilai interinsik yang ada di dalam ilmu pengetahuan, sehingga harus integral masuk dalam etos semua aktor ilmu pengetahuan di dalam lembaga akademis. Kejujuran ini menyangkut proses dalam kegiatan ilmiah, klaim kebenaran yang dihsilkan dari proses ilmiah, maupun dalam penerapan suatu ilmu pengetahuan tanpa kejujuran tidak akan di dapat kebenaran sebagaimana apa adanya. Sedangkan motif dasar ilmu pengetahuan adalah memenuhi rasa ingin tahu untuk mendapatkan pengetahuan yang benar. Sikap jujur dan obyektif. Sikap ilmiah tercermin pada sikap jujur dan objektif dalam mengumpulkan faktor dan menyajikan hasil analisis fenomena alam dan sosial melalui cara berpikir logis. Sikap jujur dan objektif menghasilkan produk pemikiran berupa penjelasan yang lugas dan tidak bias karena kepentingan tertentu.

\section{Pengetahuan Sebagai Basis Praktek}

Pengetahuan yang dimiliki manusia seharusnya menjadi jalan untuk mempraktikan semua yang diketahui, supaya mempunya dampak dalam sosial dan budaya. Olson\&Hergenhahn budaya menusia menentukan apa yang dianggap praktik-praktik yang tepat di pengadilan, pernikahan, pengasuhan anak, politik, agama, pendidikan dan keadilan, semua ini, dan variable-variabel budaya lainnya, menjelaskan banyak perbedaan individu yang penting di antara manusia yaitu perbedaan di antara individu-individu yang beda budaya. Teorisi menyatakan bahwa kepribadian manusia bisa dilihat sebagai kombinasi dari banyak peran yang dia mainkan. Jika anda diminta untuk menuliskan di selembar kertas kosong yang diawali kata aku adalah dengan sejumlah kualitas yang anda miliki, mungkin daftarnya jadi cukup banyak. $^{8}$

Peran perilaku yang bisa diterima dan tidak pada umumnya disebut norma, merupakan sesuatu yang berasal dari pengetahuan individu yang didapat dari proses belajar dari lingkup keluarga hingga sosial. Perilaku menyimpang dari jangkauan yang bisa diterima, atau menyimpang dari norma, tentulah anda bakal menemui tekanan sosial dari tipe kualitas

\footnotetext{
${ }^{8}$ Ibid. Hal.295
} 
tertentu. Bahkan, pendefinisian masyarakat bagi perilaku yang bisa diterima atau tidak telah menentukan cara anda bersikap terhadap ekspektasi sosial tersebut yang kadang melampaui kemampuan persepsi individu, sehingga memunculkan beranika ragam determinan. Determinan-determinan sosialbudaya lain bagi kepribadian meliputi tingkat sosial-ekonomi keluraga individu, jumlah anggota (ukuran) keluarganya, urutan kelahirannya, identitas etnisnya, agamanya, wilayah tempatnya dibesarkan, tingkat pendidikan orangtuanya, dan lain-lain. Individu yang diasuh di keluarga berkecukupan tentulah memiliki pengalaman yang berbeda ketimbang yang diasuh di keluarga yang berkekurangan. Situasi-situasi tak terelakkan di mana seseorang lahir dan dibesarkan (seperti jenis budaya, lingkungan masyarakat dan keluarga) memiliki dampak yang besar bagi kepribadian. Jadi paradigma ini diterima setiap teorisi kepribadian hanya saja seberapa jauh mereka bisa menerimanya, itulah membedakan.

Manusia mungkin memang sudah terlempar oleh situasi tertentu yang melampaui kemampuan mereka mengendalikan kondisi tertentu kehidupan, tetapi bagaimana persisnya mereka menilai, menginterpretasikan dan meresponya, semata-mata ini ini adalah pilihan pribadi, dan mengandung konsekuensi tetentu. Contohnya, anda mungkin terlahir sebagai pria atau wanita, miskin atau kaya, di masa damai, perang, kelaparan atau wadah penyakit. Anda mungkin mengalami aniaya di masa kecil entah secara fisik atau seksual, atau anda diasuh oleh orang-orang dewasa yang menyayangi anda sehingga masa kecil terasa menyenangkan. Tidak peduli di kondisi apa anda temukan diri anda berada, atau pengalaman apa yang anda miliki, pada akhirnya andalah yang memberikan mana ke hal-hal ini, apa pun itu. Andalah yang bertanggung jawab dengan hidup anda, karena itu, andalah yang bertanggung jawab dengan jenis kepribadian yang anda miliki. Kepribadian seseorang berisi sesuatu yang kongkrit dan ada juga yang abstrak seperti hal-hal spritual yang dapat disentuh dengan nilai keagamaan individu.

Agama bersifat transenden. Sementara psikologi bersifat profan. Psikologi tidak bisa memasuki wilayah ajaran agama. Psikologi dengan watak profannya, sangat terikat dengan pengalaman dunia semata, sementara agama merupakan urusan Tuhan yang tidak terikat dengan pengalaman hidup manusia. pemahaman yang benar terhadap hakekat psikologis manusia dalam psikologi Islam diberikan gambaran dengan pendekatan nilai-nilai keagamaan. Merumuskan sebuah definisi suatu ilmu yang mencakup dua substansi "ilmu" yang berbeda watak tentu tidak mudah. Bila rumusan definisi keliru, bisa jadi akan menimbulkan kesan "penggerogotan" terhadap wilayah ajaran agama yang suci, sehingga 
Psikologi Islam dapat menjadi penyeimbang dalam memenuhi kebutuhan psikologis manusia yang sebelumnya susah untuk dikafer oleh psikologi sekuler.

Psikologi sekuler digunakan untuk memahami perilaku umat Islam, maka akan terjadi banyak masalah. Psikologi dipahami bukan sebagi ilmu jiwa, tetapi saat ini dipahami sebagai ilmu perilaku organisme. Sementara dalam Islam, jika merujuk pada tokoh seperti Ibnu Sina, Ibnu Maskawaih dan al-Ghazali, psikologi merupakan bagian dari filsafat. Karena itu, dalam bahasa Arab, psikologi identik dengan ilmu nafs. Lantas, kenapa ilmu jiwa tidak menjadi bagian dari dalam psikologi modern, karena jiwa tidak bisa dipelajari. Sehingga di Barat, dengan pola berpikirnya yang positivistik itu tidak memasukkan jiwa sebagai bagian dari kajian psikologi, makannya psikologi dimaknai sebagai ilmu perilaku. Karena perilaku bisa dieksprimentasi dan eksplorasi secara empiris sedangkan jiwa tidak bisa. Itulah sejarah perkembangan Psikologi Islam, yang hadir untuk mengembalikan psikologi dari akarnya.

Psikologi Islam mengajarkan bagaimana seseorang dapat mengintegrasi kehidupan dengan melihat keadaan tidak dalam satu pandangan, tapi dengan menghadirikan banyak kesempatan pada pandangan yang lain, seperti psikologi Islam. Psikologi Islam memberikan intensitas berdialog yang luas dengan ajaran agama Islam secara menyeluruh yang mencakup aqidah, syariat, dan akhlak (hakikat, tasawuf). Psikologi Islam tidak hanya menggunakan paradigma epistimologi humanistik yang cenderung materialistik-ateis, melainkan juga menggunakan paradigma epistimologi empirik, epistimologi spiritual. Psikologi Islam secara bersinergi mulai mendiskusikan dan melibatkan pengaruh ajaran Islam, termasuk ajaran sufistik, terhadap orang yang meyakininya dalam pengembangan studinya.

Besarnya perhatian Islam terhadap ilmu pengetahuan, menarik perhatian Franz Rosenthal, seorang orientalis, dengan mengatakan: "Sebenarnya tak ada satu konsep pun yang secara operatif berperan menentukan dalam pembentukan peradaban Islam di segala aspeknya, yang sama dampaknya dengan konsep ilmu. Hal ini tetap benar, sekalipun di antara istilah-istilah yang paling berpengaruh dalam kehidupan keagamaan kaum muslimin, seperti "tauhîd" (pengakuan atas keesaan Tuhan), "al-dîn" (agama yang sebenar-benarnya), dan banyak lagi kata-kata yang secara terus menerus dan bergairah disebut-sebut. Tak satupun di antara istilah-istilah itu yang memiliki kedalaman dalam makna yang keluasan dalam penggunaannya, yang sama dengan kata ilmu itu.Tak ada satu cabangpun dalam kehidupan intelektual kaum muslimin yang tak tersentuh oleh sikap 
yang begitu merasuk terhadap "pengetahuan" sebagai sesuatu yang memiliki nilai tertinggi, dalam menjadi seorang muslim."

Penjelasan-penjelasan al-Qurān dan al-Hadīts di atas menunjukkan bahwa paradigma ilmu dalam Islam adalah teosentris. Karena itu, hubungan antara ilmu dan agama memperlihatkan relasi yang harmonis, ilmu tumbuh dan berkembang berjalan seiring dengan agama. Karena itu, dalam sejarah peradaban Islam, ulama hidup rukun berdampingan dengan para ilmuwan. Bahkan banyak ditemukan para ilmuwan dalam Islam sekaligus sebagai ulama. Misalnya, Ibn Rusyd di samping sebagai ahli hukum Islam pengarang kitab Bidāyah al-Mujtahīd, juga seorang ahli kedokteran penyusun kitab alKullīyāt fĩ al-Thibb.

Persoalan selanjutnya ialah sejauh mana akal sebagai kualitas istimewa yang diberikan Tuhan dan telah banyak menimbulkan perdebatan baik dalam hubunganya dengan manusia itu sendiri atau realisasinya dengan yang lain (the other), harus berperan ketika berhadapan dengan wahyu, apakah akal mampu mengantarkan manusia pada pengetahuan yang bisa membuatnya tetap menyadari dan terikat dengan Tuhan. Bagi para pemikir muslim klasik seperti al-Ghazali, Jalal al-Din Rumi, al-Razi, akal memiliki sisi negatif yang harus di sadari dan di waspadai, dan mereka menyatakan akan pentingnya pengetahuan yang bersumber dari atas secara langsung yang disebut intuisi atau wahyu. Sementara Ibn Sina, Ibn Arabi, dan alSyirozi menganggap akal mampu menghantarkan manusia pada pengetahuan yang hakiki.

Akal dan wahyu selalu menjadi pembahasan menarik dalam pemikiran Islam. Dari dulu hingga saat ini, ini dikarenakan karena ajaran dasar agama Islam itu sendiri yang di turunkan melalui wahyu kepada seorang nabi agar wahyu tersebut disampaikan kepada umat manusia dan pada sisi lain islam juga sangat menghargai akal serta kedudukanya, dan menjadikannya sebagai alat untuk memahami wahyu. Oleh karena itu munculah pandangan beragam mengenai peran dan keberadaan akal dan wahyu, pandangan tersebut terbagi dua, sebagian kalangan meyakini akal dan wahyu selaras. Adapun pandangan kedua melihatnya secara konfliktual, bahwa wahyu harus diutamakan karena akal menyesatkan karena itu harus dihindari. ${ }^{10}$

\footnotetext{
${ }^{9}$ Rahardjo. 1970. Ungkapan Rosenthal tersebut dikutip oleh Dawam dalam karya Rosenthal berjudul Knowledge Triumphant: The Concept of Knowledge in Medieval Islam (Leiden: E.J. Brill): hal. 57

${ }^{10}$ Ibn Rushd, Fasl al-Maqal, (Mendamaikan Agama dan Filsafat), terj. Aksin Wijaya, (Yogyakarta: Nuansa Aksara 2005), h, 1.
} 


\section{Perilaku Sebagai Kebutuhan Diri Individu}

Psikologi Islam mengkaji prinsip-prinsip studi psikologis pada manusia. Psikologi Islam tidak hanya membicarakan soal benar atau salah ajaran agama (Islam). Karenanya, kebenaran yang dicari psikologi Islam bukan hanya kebenaran teologis ataupun kebenaran fikih/syariah, melainkan kebenaran psikologis juga. Maka pembicaraan mengenai "bagaimana manusia beriman misalnya?" kajianya menekankan pada tindakan "gejalagejala keberimanan secara psikologis yang ada dalam keseharian". Begitu pula dalam hal "mengapa manusia berkelakuan agamais, psikologi agama tidak hanya membahas motif-motif bersifat teologis metafisis, juga berbicara "motif-motif yang mampu disentuh dan observeable secara psikologis. ${ }^{11}$ Perilaku itu akan memberikan pengaruh terhadap self.

Self adalah sistem kontak di batas kontak pada suatu saat. Self ada di mana terdapat batas-batas dari kontak kegiatannya adalah membentuk berbagai figur dan latar. Self selalu mengintegrasikan indra, koodinasi motorik, dan kebutuhan-kebutuhan organik. Self adalah integrator atau seniman kehidupan dan meskipun self "hanyalah sebuah faktor kecil dalam seluruh interaksi antara organism dan lingkungan. Self memainkan peran krusial, yaitu menemukan dan menciptakan makna yang kita tumbuhkan. Self terdiri atas identifikasi-identifikasi dan alienasi-alienasi di batas kontak. Sebagai contoh, individu mungkin mengidentifikasikan diri dengan keluarganya, tetapi merasa asing dengan orang-orang dari Negara lain. Di dalam batas cenderung dipersepsi baik dan di luar batas cenderung dipersepsi buruk. Aktualisasi-diri dapat dilihat sebagai ekspresi dari identifikasi-identifikasi dan alinasi-alinasi yang tepat. Fungsinya sehat itu melibatkan identifikasi dengan pembentukan self-organismik seseorang, bukan menghambat rangsang berkreasi orang itu, apalagi mengalinasi apa yang secara organismik bukan miliknya.

Kreasi dari individu sangat ditentukan oleh pengetahuan dan pengelaman yang ada pada dirinya untuk dapat dituangkan dalam kehidupan keseharian. Pengetahuan menjadi stimulus untuk melihat fenomena untuk bisa mengambil manfaat atau untuk bisa menafsirkan dengan tepat apa yang nampak, kemudian hasil dari pemaknaan itu bisa dikelola dan jadi pengalaman dan prinsip hidup. Prinsip hidup dapat dijadikan kontrol dalam menjawab segala bentuk tantangan dan rintangan untuk tidak mudah menyerah dengan keadaan, sehingga dapat mengaktualisasikan setiap keinginan dengan leluasa. Mengaktualisasikan self-image di mana orang

\footnotetext{
${ }^{11}$ Nico Syukur Dister. 1994. Pengalaman dan Motivasi Beragama. Yogyakarta;
} Kanisius: hal. 201 
hidup demi gambaran tentang bagaimana dirinya seharusnya dan bukan bagaimana dirinya adanya. Perls menganggap bahwa "setiap kontrol eksternal, bahkan kontrol eksternal yang diinternalisasikan sekalipun "you should" (anda harus) menganggu kerja organism yang sehat untuk menjalankan kehidupan yang lebih baik. Orang memahami situasi di mana mereka berada di dalamnya, dan membiarkan situasi itu mengontrol tindakannya, maka mereka belajar bagaimana mengatasi hidup untuk lebih baik.

Jones menyatakan perilaku adalah keseluruhan dari berbasis eksperimen untuk mendeskripsikan hukum atau prinsip tertentu dari perilaku manusia. Sebagai sebuah teori secara keseluruhan, penekanan distingtifnya adalah pada peran kontingensi-kontingensi lingkungan dalam memengaruhi kemahiran dan pemeliharaan perilaku. Bentuk paling radikal, model perilaku melihat tindakan manusia semata-mata didapatkan dari tiga sumber, yaitu deprivasi biologis, seperti lapar dan ketengangan seksual; riwayat belajar individu; dan karakteristik dan kongensi yang disediakan oleh konteks lingkungan. Konsep-konsep seperti pikiran dan keinginan bebas merupakan peluang untuk menuangkan keinginan dan harapan dalam realitas memang disajikan bagi siapan yang menghendaki, sehigga memerlukan seseorang yang memiliki keinginan untuk belajar harus menjadi kebutuhan utama dalam menuai kemajuan yang luar biasa baik sebagai personal ataupun sosial. ${ }^{12}$

Prinsip belajar yang diperoleh secara eksperimental, model perilaku menawarkan derajat spesifikasi yang lebih tinggi dalam menganalisis perilaku manusia yang dapat diobservasi lawan dari perilaku intrapsikis, daripada yang ditawarkan oleh model-model humanistik, eksistensial, atau psikoanalitik. Banyak penelitian yang dijadikan dasar model perilaku dilakukan pada binatang seperti anjing, kucing, dan merpati. Hal ini memunculkan issu daya-generalisasi model yang banyak diambil dari binatang nonmanusia dalam setting laboratorium pada manusia dalam lingkup alamiah. Bagaimanapun, intinya tetap, yaitu bahwa di tingkat melekuler atau tingkat observasi perilaku tertentu, para pakar psikologi dan peneliti perilaku telah memberikan kontribusi distingtif pada pengembangan kerangka-kerja teoretik untuk psikis individu yang memerlukan sentuhan dari berbagai perspektif keilmuan, sehingga memunculkan kreativitas dalam hidup.

12 Richard Nelson-Jones. 2011. Teori dan Praktik Konseling dan Terapi. Yogyakarta: Pustaka Pelajar: hal. 154 
Kreativitas merupakan kemampuan seseorang melahirkan suatu yang baru, baik berupa gagasan maupun karya nyata, baik dalam ciri-ciri attitude maupun non aptitude, baik dalam karya baru maupun kombinasi dengan halhal yang sudah ada, yang semua itu relatif berbeda dengan apa yang telah ada sebelumnya. Membangun kreativitas guru membutuhkan proses yang tidaklah secara tiba-tiba. Ada proses yang megawalinya. Pertama, belajar dari pengalaman mengajar, baik itu pengalaman pribadi maupun dari guru yang lain. Kedua, rasa cinta dan kasih sayang yang mendalam terhadap murid-muridnya agar mereka menjadi manusia ideal di masa yang akan mendatang. Ketiga, adanya tanggung jawab yang mendalam terhadap tugasnya. Keempat, guru giat belajar dalam meningkatkan kualitas pengetahuan, kepribadian dan keterampilannya yang berhubungan dengan tugas dan tanggung jawabnya sebagai guru. Pola belajar dengan merasa nyaman akan menghadirkan konsistensi dalam mengerjakannya.

Perilaku konsisten telah melahirkan kepercayaan diri yang kuat dan memiliki integritas serta mampu mengelola stres dan tetap penuh gairah. Mereka yang mampu mengelola stres dengan tabah dan keuletan, memandang tekanan bukan sebagai beban, melainkan tantangan yang menyenangkan, dan memandang perubahan sebagai kesempatan untuk berkembang, ternyata mereka lebih mampu mengatasi kesulitan, lebih adaptif dan berhasil. Tetap teguh pada komitmen, positif, dan tidak rapuh kendati berhadapan dengan situasi yang menekan dirinya. Untuk keluar dari tekanan itu harus konsisten atau istiqomah dalam belajar. Istiqomah berarti tetap tangguh menghadapi badai. Berjalan sampai ke batas, berlayar sampai ke pulau. Impian adalah samudra yang paling luas untuk diarungi. Tidak ada biaya untuk bermimpi. Harga yang harus dibayar justru pada saat ingin mewujudkan impian-impian tersebut. Adapun harga yang paling tepat membayarnya adalah dengan sikap istiqomah. ${ }^{13}$ Perilaku istiqomah ini akan melahirkan harmoni dan totalitas yang luar biasa. Guru yang ideal adalah guru yang mampu berperilaku istiqomah dalam kelembutan dan kebrilianan tatkala menjalankan tugasnya. Bila dalam berinteraksi dengan peserta didiknya guru tidak melandaskan ikhtiar pada cinta kasih, ia akan menuai banyak kesulitan. Ia tak bakal mampu menjadi figur yang berwibawa di hadapan peserta didiknya.

Manusia pada dasarnya memiliki perbedaan dalam mengaitkan informasi dengan fakta, dan besarnya jumlah atau jenis informasi yang ada padanya, baik yang diambil dengan jalan menerima dari orang lain

\footnotetext{
${ }^{13}$ Tasmara, Toto. 2002. Membudayakan Etos Kerja Islami. Jakarta: Gema Insani:
} hal. 168 
(mendengar), dengan jalan menelaah (membaca), ataupun yang diambil dari pengalaman hidup. Perbedaan-perbedaan ini mempengaruhi manusia dalam taraf berpikirnya. Pada dasarnya, manusia mempunyai otak yang kuat dan juga kemampuan yang kuat dalam mengaitkan informasi dengan fakta, kecuali pada orang-orang yang diciptakan dalam keadaan lemah, atau yang mengalami kelemahan di kemudian hari. Kebanyakan manusia senantiasa mendapatkan informasi baru setiap hari, termasuk pada orang-orang yang tidak bisa membaca dan menulis. Kecuali orang-orang abnormal, yaitu orang-orang yang tidak mempunyai perhatian pada apa pun, yang tidak menghargai informasi yang disampaikan kepadanya atau informasi yang dipelajarinya sendiri. Meskipun demikian, ada individu-individu tertentu yang terbiasa berpikir dangkal dan rela dengan hasil berpikirnya itu, serta tidak merasa memerlukan sesuatu yang lebih berharga daripada yang telah ada pada diri mereka. Hal ini menyebabkan berpikir dangkal menjadi kebiasaan mereka, sehingga merekapun senantiasa berpikir dengan cara seperti itu. Mereka menyenanginya serta merasa puas dengannya.

Berpikir mendalam tidak hanya sekedar mengindera sesuatu dan tidak cukup dengan hanya informasi awal untuk mengaitkannya dengan penginderaan, seperti halnya pada berpikir yang dangkal. Berpikir mendalam dilakukan dengan mengulang penginderaan fakta dan berusaha menginderanya lebih banyak dari penginderaan sebelumnya, baik dengan jalan percobaan atau dengan mengulang penginderaan. Berpikir mendalam juga dilakukan dengan mengulang pencarian informasi-informasi lain di samping informasi-informasi awal yang telah ada. Berpikir mendalam juga dilakukan dengan mengulang pengaitan informasi dengan fakta secara lebih banyak dari yang telah dilakukan sebelumnya. Baik dengan cara mengamatinya dengan berulang-ulang atau dengan mengulangi kembali pengaitan tersebut. Dengan demikian, dari tipe penginderaan, pengaitan dan informasi yang seperti ini, akan dihasilkan pemikiran-pemikiran yang mendalam baik merupakan kebenaran maupun bukan kebenaran. Dengan mengulang-ulang dan membiasakannya maka akan terwujudlah proses berpikir secara mendalam. Berpikir mendalam adalah berpikir yang tidak cukup dengan sekedar penginderaan pertama, informasi awal, serta pengaitan yang pertama antara informasi dengan fakta. ${ }^{14}$

\footnotetext{
${ }^{14}$ Purwoko, B. Satikyono. 2012. Psikologi Islam: Teori dan Penelitian. Bandung:
} Satikyono wordpress.com: hal. 68 


\section{Epilog}

Agama adalah sumber kontrol perilaku yang dapat membawa pencerahan intelektual, batin, dan sosial manusia baik dalam keadaan senang maupun susah. Agama menjadi inspirator kekayaan rohani yang tak ternilai harganya. Ia menjadi kekuatan pengendali paling efektif dalam memandu kehidupan seseorang. Mengamalkan agama adalah perilaku agung yang mendapat jaminan kebahagiaan dunia dan akhirat, maka dari itu Psikologi Islam yang mempelajari aktivitas kehidupan manusia dapat menjadi pengendali kehidupan manusia untuk lebih baik dalam memberikan teladan.

Manusia sebagai teladan dapat dipandang sebagai orang yang memiliki citra yang baik apabila bisa menunjukkan kepada masyarakat bahwa ia layak menjadi teladan oleh masyarakat di sekelilingnya. Menjadi teladan dalam masyarakat merupakan keharusan untuk menciptakan keadaan yang kondusif dalam hidup, seorang guru harus berperilaku yang baik. Pandangan masyarakat tentang perilaku tentu selalu akan dilihat dari keseharian yang ditampilkan kepada mereka itu apakah sudah sesuai atau malah sebaliknya. Kesesuain perilaku dalam masyarakat itu sangat penting untuk dapat berinteraksi satu sama lain dengan bentuk saling memahami. Norma yang dibuat dalam masyarakat salah satu yang penting adalah untuk dapat menserasikan satu sama lain, sehingga perilaku sebagai basis utama dalam keseharian perlu mendapat perhatian yang utuh dan Psikologi Islam yang di dalamnya mengajarkan kesatuan antara linkungan sosial dan spritual harus benar-benar seimbang.

\section{Daftar Pustaka}

Djamaluddin Ancok, Fuad Nashori. 1995. Psikologi Islam: Solusi Islam atas Problem-problem Psikologi. Yogyakarta; Pustaka Pelajar.

Ibn Rushd, Faṣl al-Maqāl. (Mendamaikan Agama dan Filsafat), terj. Aksin Wijaya. Yogyakarta: Nuansa Aksara.

Matthew H. Olson \&B.R. Hergenhahn. 2011. Pengantar Teori-Teori Kepribadian. Yogyakarta: Pustaka Pelajar.

Mulyadi Kartanegara. 2005. Integrasi Ilmu: Sebuah Rek onstruk si Holistik. Bandung: Mizan Pustaka.

Nashori, H.F. 2002. Mengembangkan Kretifitas dalam Perspektif Psikologi Islam. Jogjakarta; Menara Kudus.

Nahori, H.F. dan Mucharam, R.D. 2002. Mengembangkan Kreatifitas: Perspektif Psikologi Islam. Yogyakarta; Menara Kudu. 
Nico Syukur Dister. 1994. Pengalaman dan Motivasi Beragama.Yogyakarta; Kanisius.

Quṭb, Sayyid. 2002. Tafsìr fî Zilāl al-Qur'an. Jakarta; Gema Insani Press.

Purwoko, B. Satikyono. 2012. Psikologi Islam: Teori dan Penelitian. Bandung: Satikyono wordpress.com

Rahardjo. 1970. Ungkapan Rosenthal tersebut dikutip oleh Dawam dalam karya Rosenthal berjudul Knowledge Triumphant: The Concept of Knowledge in Medieval Islam (Leiden: E.J. Brill).

Richard Nelson-Jones. 2011. Teori dan Praktik Konseling dan Terapi. Yogyakarta: Puataka Pelajar.

Sumintarja, Elmira N. 2000. Konsep manusia menurut Psikoanalisa: Eksplanasi, Kritik, dan Titik Temu dengan Psikologi Islam. Yogyakarta; Pustaka Pelajar.

Tasmara, Toto. 2002. Membudayakan Etos Kerja Islami. Jakarta: Gema Insani. 